\title{
Improving Quality of Life through Recreational Behaviour in Urban Park
}

\author{
Nurul Shakila Khalid, Nurul Faizah Baba, Hazlina Hamdan \\ Centre of Studies for Town and Regional Planning, \\ Faculty of Architecture, Planning and Surveying, \\ Universiti Teknologi MARA, Shah Alam, Selangor, Malaysia. \\ shakilakhalid@salam.uitm.edu.my
}

\begin{abstract}
Well-designed of an urban park is one of the best ways to achieve the city sustainable development and contributes to the quality of life in many ways. Central to this argument is the claim that the variables need to be considered and thus, this research was conducted to assess the quality of urban park by empirically evaluating through behavioral competencies and psychological well-being from the model of Lawton's Quality of Life. A quantitative research method was employed for the research with 134 respondents in Taman Lembah Bukit SUK, Shah Alam. Results confirm that the urban park provides the potential for psychological well-being and behavioral competencies equally among male and female in improving their quality of life.
\end{abstract}

Keywords: quality of life; urban park; behavioral competencies; psychological well-being

eISSN 2398-4279 @ 2018. The Authors. Published for AMER ABRA cE-Bs by e-International Publishing House, Ltd., UK. This is an open access article under the CC BY-NC-ND license (http://creativecommons.org/licenses/bync-nd/4.0/). Peer-review under responsibility of AMER (Association of Malaysian Environment-Behaviour Researchers), ABRA (Association of Behavioural Researchers on Asians) and cE-Bs (Centre for EnvironmentBehaviour Studies), Faculty of Architecture, Planning \& Surveying, Universiti Teknologi MARA, Malaysia.

DOI: https://doi.org/10.21834/ajqol.v3i13.164 


\subsection{Introduction}

Urban park refer to open space is defined as a public area that is used for recreational purposes without being charged with any fees and open for the public to assess every day (Department of Town and Regional Planning, 2000). Urban park, when given the focus can achieve the monumentality a form of marker for the public to engage socially (Omar, Ibrahim \& Mohamad, 2016). This thus support by several leisure research that has confirmed various recreational activities could indeed generate short-term benefits including positive mood, physical fitness, and immediate satisfaction, as well as long-term effects of enhancing happiness, mental health, and social interaction (Lu, 2011; Omar \& Ibrahim, 2015). Access to good quality, well-maintained open spaces can help to improve physical and mental health by encouraging people to walk more, to play sport, or to enjoy a green and natural environment (Ulrich \& Addoms, 1981).

However, we found that having controlled for effects of demographics, physical health, social interaction and positive leisure experiences were negatively related to indicators of well-being in urban area. An underlying spirit of the study is to extend the current literature on the subject by exploring of how urban people can improve their long-term quality of life in the urban context of Shah Alam through the higher participation of recreational activity in the urban park. The study focuses on the fundamental mission: what attributes of such paces are relevant to QoL for better using of park among inhabitants for enhanced quality of life.

\subsection{Literature Review}

\subsection{Urban Quality of Life}

Quality of life refers to as a multifaceted concept that embraces not only material aspects of life such as level of living, availability of physical and social infrastructural facilities, but also the less tangible aspects of life include good health and opportunities for recreation (Kaplan and Kaplan, 1989). The Economic Planning Unit (EPU) in its report on the Malaysian Quality of Life Index 2002, defines quality of life as encompassing personal advances, a healthy lifestyle, low crime rates and freedom to pursue education, and attaining a standard of living which surpasses the fulfillment of the basic and psychological needs of the individual, to achieve a level of social well-being compatible with the nation's aspirations (EPU, 1999). As stated in Malaysia Quality of Life Index, the QoL is determined by 12 components and over 29 indicators as a tool to measure the quality of life in Malaysia as shown in Table 1.

Unfortunately, the focus on the provision of the good design and quality of urban park still lacking despite their importance to us, our open spaces are often taken for granted or neglected. Obviously, the provision of open space is only to fulfill the $10 \%$ open space requirement applied in every housing scheme without considering the value of open space. All too often, badly designed, badly managed open spaces are in the most deprived urban areas. 
Table 1. The Components of Malaysian Quality of Life Index (MQoLI)

\begin{tabular}{|c|c|}
\hline Components & Indicators \\
\hline Income and Distribution & $\begin{array}{ll}\text { - } & \text { Per capita income } \\
\text { - } & \text { Incidence of poverty }\end{array}$ \\
\hline Working Life & $\begin{array}{l}\text { - Unemployment rate } \\
\text { - Gender equality in labour workforce }\end{array}$ \\
\hline Transport and Communications & $\begin{array}{l}\text { - } \quad \text { Private motorcars and motorcycles } \\
\text { - Internet subscribers }\end{array}$ \\
\hline Health & $\begin{array}{ll} & \text { Doctors population ratio } \\
\text { - } & \text { Maternal mortality rate } \\
\end{array}$ \\
\hline Education & $\begin{array}{l}\text { - Literacy rate } \\
\text { - Secondary and secondary school teacher-student ratio }\end{array}$ \\
\hline Housing & $\begin{array}{l}\text { - Low-cost housing units } \\
\text { - Average prices of houses to household income ratio }\end{array}$ \\
\hline Environment & $\begin{array}{l}\text { - } \quad \text { Air and water quality } \\
\text { - Forested land }\end{array}$ \\
\hline Family Life & $\begin{array}{ll}\text { - } & \text { Divorces } \\
\text { - } & \text { Household size and incomr }\end{array}$ \\
\hline Social Participation & $\begin{array}{ll}\text { - } & \text { Registered voters } \\
\text { - } & \text { Registered Voluntary Organizations }\end{array}$ \\
\hline Public Safety & $\begin{array}{ll} & \text { Crimes } \\
- & \text { Road accidents }\end{array}$ \\
\hline Urban Services & $\begin{array}{ll} & \text { Expenditure on landscaping } \\
\text { - } & \text { Expenditure on social services } \\
\end{array}$ \\
\hline Recreational and Culture & $\begin{array}{l}\text { - } \quad \text { Community planning } \\
\text { - }\end{array}$ \\
\hline
\end{tabular}

(Source: http://www.epu.gov.my/sites/defaultffiles/kualitihidup1999)

\subsection{The Dimensions of Urban Park}

Design and planning of parks can make a difference. According to Teal et al., (1998), the design, planning, and management of parks are vital to achieving sustainable urban park. Aware of this insight, park is the best ways to develop the sustainable community as well as it bring communities together, provide meeting places and foster social ties of a kinf that have been disappearing in many urban areas.

Recreational areas in a neighborhood that functional for recreation, sports, and social activities, as it can be seen in present residential development. Hence, it is important to note that, based on the population size in the study areas, the term of "urban park" in the study is to represent the green open spaces provided in residential development for the purpose of recreation activities and promoting neighbourliness. According to the Malaysian planning standard and guidelines, an urban park can be defined as a recreational area provided for urban residents in the area of 40 hectares to cater 50,000 people and above.

By referring the previous findings, Lawton (1991) conceptualized the quality of life model through four (4) components; behavioral competencies, perceived quality of life, the objective environment and psychological well-being. For this study, only the behavioral competencies and psychological well-being were measured because they are much related to the local context, physical activity that people did in the park, and the benefits of doing recreational 
activity in improving their health status, and engaging people (see Figure 1). In details, behavioral competencies focus on the social-normative assessment of an individual health, cognition, and social relationship, while psychological well-being refers to the cognitive life satisfaction and emotional well-being (positive or negative emotions).

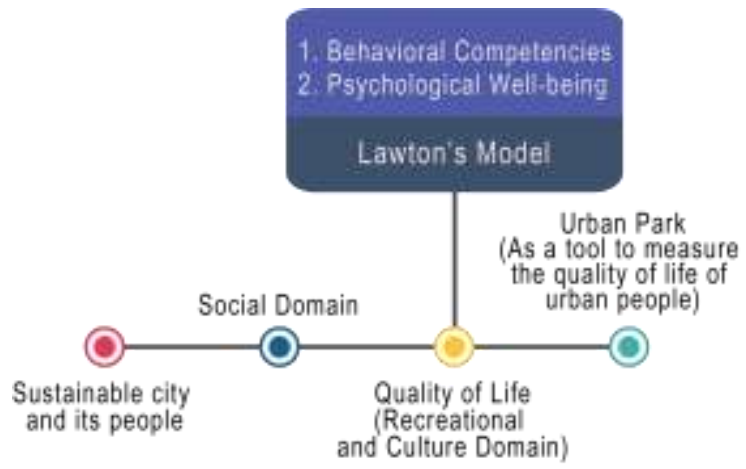

Figure 1: Lawton's Quality of Life Model

(Source: Modified from Lawton, 1991)

Lawton (1991) in the study of community-dwelling found that higher level of participation in especially in social relationship and cognitive activities can contribute to better Healthrelated Quality of Life (HrQOL) as mentioned by World Health Organization (WHO) has since 1948 defined health as a state of complete physical, mental and social well-being and not merely absence of disease or infirmity.

\subsection{Methodology}

\subsection{Data Collection and Research Design}

Methodologically, quantitative research methods were used as the method of study to identify the benefits of participation in the recreational activity in the urban park. Using semistructured questionnaire, the survey focused on the holistic experience of life rather than on actual conditions of life through the variable of psychological health, social behavior, level of satisfaction of on aspects of the urban park, and social interaction.

A total of 200 of survey questionnaires were distributed within the park randomly to the visitors who are live in the nearest neighbourhood (e.g. Section 5, 6, 9 and 11) regardless their age, sex, and ethnicity. However, only 134 reliable respondents were answer the questionnaires. The target respondents also who come to the park during the weekdays and weekend from 7 to $11 \mathrm{am}$.

The survey covers four (4) parts; Part A: Respondents' Profile, Part B: Visitor Behavior (Likert-scaled questions), Part C: Psychological Well-being, and Part D: Respondents' 
Perception. Notably, Part B: Visitor Behavior, the researcher evaluate the social interaction among the visitors that much related to the component of behavioral competencies while Part C: Psychological well-being, the respondents were asked about the emotions of happiness and comfort that later be interpreted as feelings of psychological well-being. In Part D: Respondents' perception give focus on respondents perception on recreational facilities provided in the park.

By using a 1-5 scale of satisfactory, the results of each variable converted into percentage from overall mean and standard deviation. The numbers were also divided by gender in conjunction to raise the comparison result between both male and female quality of life.

\subsection{Study Area}

The selection criteria of Taman Lembah Bukit SUK Shah Alam were based on several aspects. Shah Alam is selected to be the geographical location as it is identified as the most urbanizing area in Selangor. Also, the size of Taman Lembah Bukit SUK approximately is 40 hectares and the population size is 185,585 residents as it meet the criteria of urban park category.
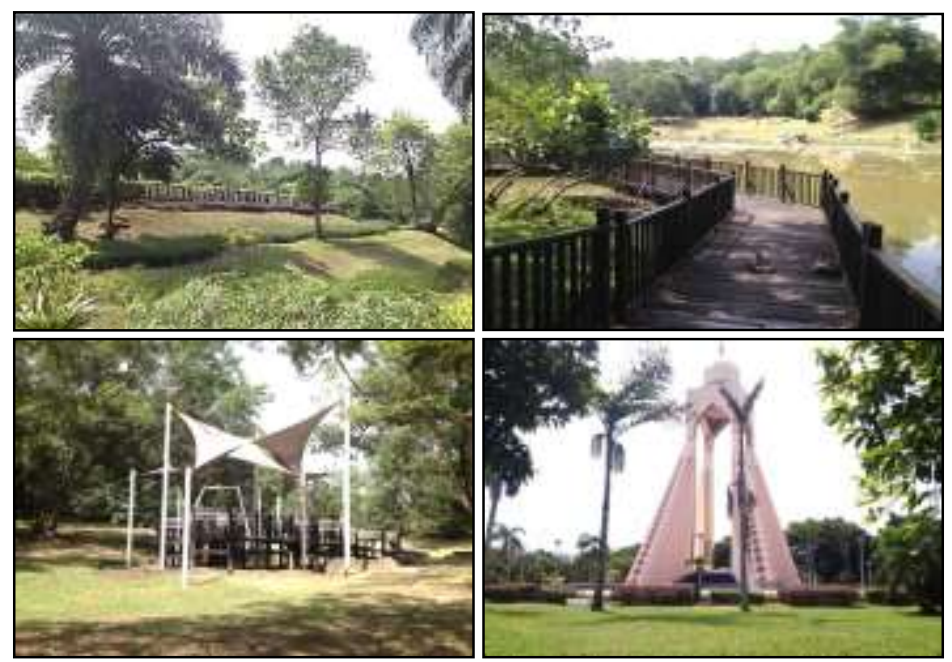

Figure 2: Recreational facilities in Taman Lembah Bukit SUK Shah Alam (Source: Author, 2017)

\subsection{Results and Discussion}

\subsection{Respondents' Profile}

The data from survey questionnaires coded into SPSS software for statistical analysis to determine the relationship of urban park variables and quality of life among park visitors. The 
recreational participation in this study can be explained based on demographic characteristics; sex, age group, ethnicity, and occupation were assessed in descriptive analysis as potential confounding variables (see Table 3 ).

Table 3. Demographics characteristic of respondents

\begin{tabular}{|c|c|c|c|c|c|}
\hline \multirow[t]{2}{*}{ Respondents' Profile } & \multirow[t]{2}{*}{ Variable Measured } & \multicolumn{2}{|c|}{ Sex } & \multirow[t]{2}{*}{$\mathrm{N}=134$} & \multirow[t]{2}{*}{$\%$} \\
\hline & & Male & Female & & \\
\hline \multirow[t]{5}{*}{ Age Group } & $12-18$ years old & 2 & 2 & 4 & 5.2 \\
\hline & 19-24 years old & 30 & 20 & 50 & 33.5 \\
\hline & $25-30$ years old & 23 & 29 & 53 & 32.0 \\
\hline & $31-50$ years old & 11 & 10 & 21 & 17.3 \\
\hline & 51 years old and above & 3 & 4 & 7 & 12.0 \\
\hline \multirow[t]{2}{*}{ Marital Status } & Single & 33 & 37 & 70 & 52 \\
\hline & Married & 29 & 35 & 64 & 48 \\
\hline \multirow[t]{3}{*}{ Ethnicity } & Malay & 41 & 38 & 79 & 59 \\
\hline & Chinese & 16 & 31 & 47 & 35 \\
\hline & Indian & 4 & 4 & 8 & 6 \\
\hline \multirow[t]{7}{*}{ Occupation } & Professional & 6 & 5 & 11 & 8.2 \\
\hline & Government & 12 & 8 & 20 & 15.3 \\
\hline & Private & 11 & 14 & 25 & 18.7 \\
\hline & Self-employed & 4 & 12 & 16 & 12.0 \\
\hline & Pensioner & 3 & 2 & 5 & 3.8 \\
\hline & Student & 31 & 22 & 53 & 39.0 \\
\hline & Unemployed & 2 & 2 & 4 & 3.0 \\
\hline
\end{tabular}

(Source: Author, 2017)

Analysis of participation among age group shows that adults between 19 to 50 years old consistently exhibited higher participation rates in the park. The mean age of the sample was 25 to 35 years old and $39.0 \%$ of the respondents were the student who actively participates in recreational activity as it given that the study area is near to UiTM and secondary schools. In overall, the respondents are balanced between male and female respectively 66 (49.2\%) and $68(50.8 \%)$. The cross-sectional analysis between gender, age and occupation slightly show that women of age 19 to 50 years old resulted 68 of the total respondents are married and single, and 39 of them are working women. The types of occupation and marital status shows the strong relationship that describes the factor that may contribute to the higher participation of woman in recreation activity in the park. However, the results of male participation almost balance. This also suggests that both male and female today really aware the benefits of recreational activity and practice the healthy lifestyle. This finding suggests that both male and female have equality in recreational opportunity.

\subsection{Analysis for Quality of Life}

Results of the study focus on the quality of life index among the visitors in Taman Lembah Bukit SUK in this marginalized according to descriptive analysis. Table 4 reports the quality of life index for the 134 samples (n-134). Chi-square was used to the test the significant relationship between behavioral competencies and psychological well-being and the four (4) variables; social interaction, health status, level of satisfaction, and respondents' emotion. 


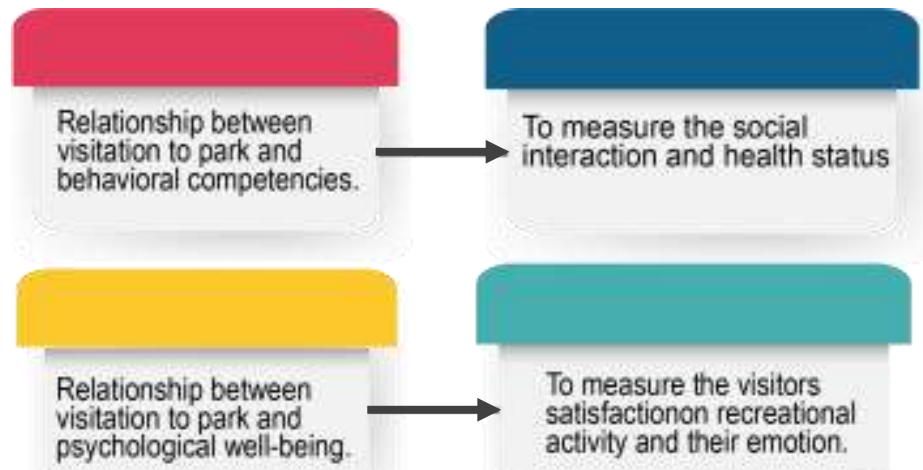

Figure 3: The relationships of variables indicate the behavioural competencies and psychological well-being.

(Source: Author, 2017)

The result analysed in SPSS, and the analysis using Chi-square and $p$-value methods were applied. At $5 \%$ level of significant, $p$-value $<0.05$. In the following paragraphs results obtained will be presented and discussed.

Table 4: Results of Chi-square of behavioral competencies and psychological well-being

\begin{tabular}{l|c|c|c|cc}
\hline Quality of Life Attributes & \multicolumn{2}{|c|}{ Chi-square } & \multirow{2}{*}{ df } & \multicolumn{2}{c}{$p$-value } \\
\cline { 2 - 3 } \cline { 5 - 6 } & Male & Female & & Male & Female \\
\hline Behavioral Competencies & & & & & \\
Social interaction & 4.237 & 2.096 & 4 & 0.03 & 0.01 \\
Health status & 3.551 & 1.778 & 4 & 0.04 & 0.02 \\
& & & & & \\
Psychological well-being & & & & & \\
Level of satisfaction & 1.843 & 3.699 & & & \\
Emotional dimensions & 2.259 & 1.173 & 4 & 0.02 & 0.04 \\
\hline
\end{tabular}

*Significant level at $p<0.05$

For social interaction, the respondents were asked about their experience in interactwith friends or other visitors when they come to the park. Table 4 shows at $5 \%$ level of significant, Chi-square value $=4.237$ and 2.096, $p$-value $=0.03$ and $001<0.05$ is significant. There is a relationship between recreation and social interaction because park is the suitable place for social interaction and the relationship establish may be longer.

Respondents' health status was measured as the number of days in the last 30 days in which poor physical and/or mental health prevented them from carrying out the daily routine and recreational activity. Whereas health is a consideration, the result should not neglect the long-term well-being of the urban inhabitants which has a lot more to do with psychologically. Respondents reported on average 7 days of unhealthy days in the last 30 days. At $5 \%$ level of significant, Chi-square $=3.551$ and 1.778, $\mathrm{p}$-value $=0.04$ and $0.02<0.05$. There is a 
relationship between recreational activity and health status, and this shows health and recreation are interrelated. The level of individual health may be influenced by other factors such as dieting menu and lifestyle. However, participation in the recreational activity in the park is one way to have life satisfaction and healthy lifestyle especially live in a densely populated city.

For level of satisfaction of on the aspects of urban park, the respondents were asked to rate their level of satisfaction that they experienced in the park. Both male and female shows that at $5 \%$ level of significant, Chi-square value $=1.843$ and 3.699 respectively, $p$-value $=$ 0.02 and $0.04<0.05$ is significant. There is a relationship between level of satisfaction on the aspects of urban park such as location, facilities, safety, landscape elements and others. The respondents were concerns more on the physical aspects in park because they not only do the recreation activity but they want to experience the park.

For emotional dimension of the parks' experience, the respondents were asked which feeling does nature evokes them. Their answers mostly such as adventure, unity with themselves and nature, happiness and relieve. All these emotion much relates to positive feelings, which recreate the spirit and recharge the energy. In Table 4 shows at $5 \%$ level of significant, Chi-square $=2.259$ and 1.173 , p-value $=0.02$ and $0.01<0.05$ is significant and no significant differences among male and female with regard to the emotional experiences. The result shows that there is a relationship between recreation and people feelings. With the term "recreation" this do not refer to the particular activities people engage in during their recreational time in park, but rather to the sense of relaxation and enjoyment that the very experience of park and nature promotes.

\subsection{Conclusion}

This study has added to our understanding of the ways in which urban living environments are associated with its inhabitants' quality of life. Growing concerns over the provision of the urban park as studies on quality of life among urban people importantly point to the benefits of participating in the recreational activity to achieve life satisfaction and to be more sensitive to the social implications of any physical design and planning. Overall, the quality of parks was found relevant to peoples' life satisfaction, whereas the quality of health was correlated with the level of happiness and satisfaction, regardless of respondents' age, sex, occupation, ethnicity, and marital status. The success of a park needs consideration of several criteria as revealed in this study; location, safety, recreational facilities, landscape elements, activities, and maintenance and management.

\section{References}

Abdul Malek, N., Mariapan, M., Kamal, M., \& Shariff. (2011). Assessing the Needs for Quality Neighbourhood Parks. Australian Journal of Basic and Applied Sciences, 5(10), 743-753.

Abdul Malek, N., Mariapan, M., \& Ab Rahman, N. I. A. (2015). Community Participation in Quality Assessment for 
Green Open Spaces in Malaysia. Procedia-Social and Behavioral Sciences, 168, 219-228.

Dergance, J. M., Calmbach, W. L., Dhanda, R., Miles, T. P., Hazuda, H. P., \& Mouton, C. P. (2003). Barriers to and Benefits of Leisure Time Physical Activity in the Elderly: Differences Across Cultures. Journal of the American Geriatrics Society, 51(6), 863-868.

Guidelines and Planning Standard for Open Space and Recreation (2000). Department of Town and Country Planning, Peninsular Malaysia.

Kaplan, R., \& Kaplan, S., (1989). Experience of Nature: A Psychological Perspective. Cambridge University Press, New York.

Lawton, M. P. (1991). A Multidimensional View of Quality of Life in Frail Elders. In James, E. et al., (ed), The Concept and Measurement of Quality of Life in the Frail Elderly. Psychology, 3-27.

Lu, L. (2011). Leisure and Depression in Midlife: A Taiwanese National Survey of Middle-aged Adults. Journal of Health Psychology, 16(1), 137-147.

Omar, K. A., Omar, D., Othman, S., \& Yusoff, Z. M. (2017). Youth in Public Housing: Place attachment and Quality of Life Index. Environment-Behaviour Proceedings Journal, 2(5), 325-332.

Omar, D., Ibrahim, F. I., \& Mohamad, N. H. N. (2016). Evaluating Multi-dimensional Human Needs in Open Spaces: Taman Tasik Shah Alam, Selangor, Malaysia. Environment-Behaviour Proceedings Journal, 1(2), 96-105.

Omar, D., \& Ibrahim, F. I. (2015). Human Interaction in Open Spaces. Procedia-Social and Behavioral Sciences, 201, 352-359.

Sajin, N. B., Dahlan, A., \& Ibrahim, S. A. S. (2016). Quality of Life and Leisure Participation amongst Malay Older People in the Institution. Procedia-Social and Behavioral Sciences, 234, 83-89.

Teal, M., Huang, C. S., \& Rodiek, J. (1998). Open Space Planning for Travis Country, Austin, Texas: A Collaborative Design. Landscape and Urban Planning, 42(2), 259-268.

Ulrich, R. S., \& Addoms, D. L., (1981). Psychological and Recreational Benefits of a Residential Park. Journal of Leisure Research, 13(1), 43. 